\title{
Plant spacing and pollen quantity on yield and quality of squash seeds ${ }^{1}$
}

\author{
Márcio S. de Lima; Antonio I. I. Cardoso; Marcelo F. Verdial
}

UNESP, Depto. Produção Vegetal, C. Postal 237, 18603-970, Botucatu-SP; E-mail: marcio.lima@sakata.com.br

\begin{abstract}
Squash seeds yield and quality can be improved by proper population plant spacing and the pollen quantity, which influences the pollination quality and fertilization. Nine experiments were conducted as a factorial combination of three spacing between plants $(0.8 \times 0.3,0.8 \times 0.6$ and $0.8 \times 0.9 \mathrm{~m})$, two quantities of pollen $(50 \%$ of an anther and another entire one) and natural insect pollination. Seed and fruit production parameters, and seed quality were evaluated. A randomized complete block design, five replications, with ten plants per plot was adopted. Larger plant spacing increased the average number of mature fruits and seed yield per plant. Seed yield was directly proportional to the amount of pollen used during pollination. Higher amounts of pollen resulted in higher seed yield per area, but the plant spacing did not affect this characteristic. Manual pollination, using a whole anther, did not differ from natural pollination in relation to seed yield and quality.
\end{abstract}

Keywords: Cucurbita pepo L., pollination, germination, vigor.

\section{RESUMO}

Efeito do espaçamento entre plantas e quantidade de pólen sobre o rendimento e a qualidade de sementes de abóbora

O rendimento e a qualidade de sementes de abóbora podem ser aprimorados por uma densidade populacional de plantas adequada, além da quantidade de pólen, que influi na qualidade da polinização e fertilização. Para este estudo, aplicaram-se nove tratamentos, que resultaram da combinação fatorial de três espaçamentos entre plantas $(0,8 \times 0,3 ; 0,8 \times 0,6$ e $0,8 \times 0,9 \mathrm{~m})$ com duas quantidades de pólen ( $50 \%$ de uma antera e uma antera inteira) e a polinização natural por insetos. Foram avaliados parâmetros de produção de frutos e sementes, além da qualidade física e fisiológica das sementes. O delineamento experimental adotado foi em blocos ao acaso com cinco repetições e dez plantas úteis por amostragem. O aumento do espaçamento entre plantas elevou o número médio de frutos maduros e a produção de sementes por planta. A produtividade de sementes foi diretamente proporcional à quantidade de pólen usada durante a polinização. Já o fator espaçamento entre plantas não afetou a produção de sementes por área. A maior quantidade de pólen resultou em uma maior produção de sementes por planta e por área. A polinização manual, com a utilização de uma antera inteira, não diferiu da polinização natural com insetos, tanto para rendimento como para a qualidade de sementes.

Palavras-chave: Cucurbita pepo L., polinização, germinação, vigor.

(Recebido para publicação em 21 de março de 2002 e aceito em 24 de abril de 2003)

$\mathrm{U}^{\mathrm{s}}$ sing seeds with high physiological, physical, sanitary and genetic quality is a prior factor to achieve profitability on vegetable production. The wide use of hybrid seeds led growers to require high quality seeds, as long as these seeds are more expensive than seeds obtained through open pollination. On the other hand, some factors that would improve seed yield and seed quality should be considered in order to obtain competitive prices in the market.

In a regular crop development, the growth of vegetative parts must precede the reproductive ones. Heuvelink, mentioned by Andriolo (1999), showed that an ideal population density was necessary for an optimized leaf area index (LAI), so that the maximum useful radiation for photosynthesis would be intercepted. On high density plantings, an optimized LAI can be reached very early, before plants start the reproductive phase. Thus, planting density influences plant growth, changing the emission of flowers and fruits and interfering on the biomass distribution between vegetative parts and fruits.

Obtaining optimum plant population in seed production is one of the ways to guarantee high yield. In addition, when population is increased, fruits and seeds per plant are reduced, and seed size is increased (Nakagawa, 1986). However, Demattê et al. (1978) showed that increasing competition between squash plants (Cucurbita pepo L.) resulted in both lower seed number and seed weight.

To obtain a higher seed production in C. pepo, Loy (1988) considers the increase of plant density and fruit number per plant a prior factor. In higher plant densities $\left(35,000\right.$ plants.ha $\left.{ }^{-1}\right)$ seed weight and fruit number per plant were lower; however seed yield per hectare was higher when compared to low densities $\left(8,000\right.$ plants.ha $\left.^{-1}\right)$. This author concluded that 14,000 plants.ha ${ }^{-1}$ would be an adequate population with a plant spacing of $1.2 \times 0.6 \mathrm{~m}$. This planting density provided $44.4 \mathrm{~g}$ of seeds per plant, and a higher value (28.2\%) of "seed index" (relation between seed dry and fruit dry weight). Using 14,000 plant.ha ${ }^{1}$ resulted in 2.1 fruits.plant ${ }^{-1}$ and

\footnotetext{
${ }^{1}$ Parte da dissertação de mestrado do primeiro autor apresentada à UNESP, Botucatu (SP).
} 
highest seed weight per fruit $(21.0 \mathrm{~g})$. Edelstein et al. (1985) reported that different population densities of Spaghetti Vegetable squash did not affect the seed size or germination, but in high-density populations, the yield was slightly lower due to a reduced number of seeds per fruit.

The pollen amount applied to $C$. pepo female flowers may influence fruit and seed yield substantially. According to Schlichting et al. (1987), applying higher pollen amount resulted in bigger fruits (376 seeds) in comparison to a lower pollen amount application, which resulted in smaller fruits (40 seeds). According to Ávila et al. (1989), the manual pollination can be as effective as the natural one, considering the number of fruits per plant. However, it was less effective in yielding seeds per plant.

In the Cucurbita genus, the use of manual pollination with one or more anthers per female flower is largely used in hybrid seed production in Brazil, being necessary to guarantee the fruit set, seed production and genetic purity. The natural pollination by bees (Apis mellifera is considered the main Cucurbita genus pollinator in Brazil) is cheaper than manual pollination. Little information is available regarding Cucurbita natural pollination, but other insect families, such as Halictidae (Pseudougochloropis sp.), Xylocopidae (Xylocopa sp.), and Trigona rufricus have been researched in Cucurbita flowers in Brazil (Couto et al., 1990). To permit insect pollination, the chemical spraying should be done in the afternoon, and the pesticides should not be toxic to bees.

An important factor for yield and quality of hybrid seeds is the relation between the numbers of plants or flowers related to paternal and maternal lines. Viggiano (1990) described that for squash hybrid seed production, intercalated progenitor lineage, two lines of male genitor and four lines of female genitor must be planted. This plant's relation must not be extrapolated for male flowers related to the female ones, as the number of male flowers in a $C$. pepo cycle is usually higher than the number of female ones.
The aim of this work was to verify the influence of plant spacing and pollen amount on yield and quality of squash seeds.

\section{MATERIAL AND METHODS}

The experiment was carried out at Faculdade de Ciências Agronômicas in Botucatu, Brazil, from August to December, 1998. The sowing of the squash Caserta CAC Melhorada cultivar was done in expanded polystyrene trays (128 cells) containing the commercial substrate Plugmix (mixture of pinus bark, fine vermiculite and turf).

The nine treatments resulted from the factorial combination of three plant spacing $(0.8 \times 0.3 \mathrm{~m}, 0.8 \times 0.6 \mathrm{~m}$ and $0.8 \times 0.9 \mathrm{~m})$ and three pollination types: two pollen amounts $(50 \%$ of an anther and another entire one) and an insect natural pollination. A randomized block design, five replications and ten plants per plot were used.

A week before seedling transplanting, soil was fertilized with $150 \mathrm{~g} \cdot \mathrm{m}^{-2}$ of $4-14-8,20 \mathrm{~g} \cdot \mathrm{m}^{-2}$ of nitrocalcium and $7 \mathrm{~L} . \mathrm{m}^{-2}$ of organic matter. Plantlets with two or three expanded leaves were transplanted to the field fifteen days after sowing date. During crop management, the area was maintained free of weeds by manual bewailing. Irrigation was done using a sprinkler system. Maintenance fertilization was done with nitrocalcium (10 g.plant $\left.{ }^{-1}\right)$ twice during the crop management.

Daily controlled pollination was done during eighteen consecutive days, starting 47 days after sowing. For manual pollination, petal tips of selected male and female flowers were tied up in the afternoon before pollination. Pollination was done on the next morning in two different ways: the anthers would be leant by the female flowers stigma leaving all the pollen adhered (in case an entire anther is used) and using a razor to divide the anther in two halves (obtaining half the pollen of an anther). The anther was rolled around the stigma to permit better pollination. The male flowers were picked randomized in the field. After pollination the female flowers were closed with a small "butter paper" bag to avoid insect pollination. Out of standard anthers (small and with little pollen) were disposed. A small amount $(0.0134 \mathrm{~g})$ of pollen per anther was obtained and weighted in environment hygroscope equilibrium conditions.

The fruits were harvested when the morphological maturation stage was reached, showing a yellow color, after 90-102 days of the sowing date or 53 days between the beginning of the blooming and the harvesting seasons. The fruits were left to rest for fifteen days in a shaded place before seed extraction (Araújo et al., 1982).

For seed extraction the fruits were cut manually and seeds were washed and separated by density to classify them. These seeds were used to obtain the weight and the number of seeds per plant and per area. The seed moisture content was established in $8.0 \%$.

To obtain the fruit and seed dry matter, fruits and seeds were placed in a FANEM oven, model $315 \mathrm{SE}$, at $105^{\circ} \mathrm{C}$, during twenty four hours (Brasil, 1992). The relation between the seed dry matter weight and the fruit dry matter weight (Seed Index - SI) was obtained (Loy, 1988).

A standard germination test (SG) was conducted, according to Brasil (1992). The first count was done on the fourth day, and the final count on the eighth day after sowing. Seeds were considered germinated when the cotyledon leaves were noted, i.e., when the embryo could be seen leaving the seed testa. The first count was considered as a seed vigor test.

Seed vigor was also obtained through the emergence velocity index (EVI). The methodology to obtain emerged seedlings was adapted from Vieira \& Carvalho (1994). Seeds were sown in polyestirene trays with commercial substrate. Seedling was considered emerged when cotyledon leaves, without a seed testa protection, opened in ' $\mathrm{V}$ '. The counting of emerged seedlings was carried out on the $4^{\text {th }}$ (first emerged seedlings), $5^{\text {th }}, 6^{\text {th }}$ and on the $7^{\text {th }}$ day after the sowing (last day with new emerged seedlings), always at 8 a.m. Equation used to EVI calculation was adapted from Silva \& Nakagawa 
Table 1. Mature fruit number per plant (MFNP), seed number per plant (SNP), seed number per hectare (SNha), seed yield per plant (SYP), seed yield per ha (SYha) and Seed Index (SI) according to plant spacing (PS) and pollen amount (PA) in Caserta squash. São Manuel, UNESP, 1998.

\begin{tabular}{lcrrrrc}
\hline \multicolumn{1}{c}{ PS $(\mathbf{m})$} & MFNP & SNP & SNha & SYP $(\mathbf{g})$ & SYha $(\mathbf{k g})$ & SI $(\%)$ \\
\hline $0,8 \times 0,3$ & $0,67 \mathrm{~b}$ & $79,98 \mathrm{c}$ & $2665890 \mathrm{a}$ & $7,82 \mathrm{c}$ & $252,61 \mathrm{a}$ & $16,94 \mathrm{c}$ \\
$0,8 \times 0,6$ & $0,89 \mathrm{a}$ & $162,69 \mathrm{~b}$ & $2711560 \mathrm{a}$ & $17,38 \mathrm{~b}$ & $291,36 \mathrm{a}$ & $21,77 \mathrm{~b}$ \\
$0,8 \times 0,9$ & $0,95 \mathrm{a}$ & $230,68 \mathrm{a}$ & $2563100 \mathrm{a}$ & $27,39 \mathrm{a}$ & $308,35 \mathrm{a}$ & $25,44 \mathrm{a}$ \\
\hline PA & & & & & \\
\hline Natural & $0,82 \mathrm{a}$ & $171,32 \mathrm{a}$ & $2957740 \mathrm{a}$ & $18,96 \mathrm{a}$ & $313,73 \mathrm{a}$ & $24,43 \mathrm{a}$ \\
$50 \%$ anther & $0,84 \mathrm{a}$ & $132,21 \mathrm{~b}$ & $2207100 \mathrm{~b}$ & $15,27 \mathrm{~b}$ & $239,49 \mathrm{~b}$ & $17,47 \mathrm{~b}$ \\
$100 \%$ anther & $0,84 \mathrm{a}$ & $169,82 \mathrm{a}$ & $2875100 \mathrm{a}$ & $18,37 \mathrm{a}$ & $299,10 \mathrm{a}$ & $22,26 \mathrm{a}$ \\
\hline $\mathrm{CV}(\%)$ & 13,91 & 21,52 & 27,66 & 19,65 & 22,06 & 9,64 \\
\hline
\end{tabular}

Average in the same column followed by the same letter did not differ by Tukey test $(5 \%)$.

(1995) to obtain the seed germination velocity index.

Analysis of variance of evaluated characteristics was done and means compared by the Tukey probability test $(5 \%)$.

\section{RESULTS AND DISCUSSION}

\section{Seed yield}

The number of fruits per plant was lower with lower plant spacing, although just the $0.3 \mathrm{~m}$ spacing between the plants was statistically lower (Table 1). The occurrence of less fruits in low plant spacing is mentioned by Demattê et al. (1978). Probably the increasing competition for place, light and nutrients reduced fruit set, influencing the number of fruits per plant. No statistical difference between both natural and manual pollination was observed in the number of fruits per plant. This statement confirms Ávila et al. (1989), who mentioned that the manual pollination was as effective as natural pollination regarding the number of fruits per plant. The results showed that the pollen amount applied to squash female flowers did not affect significantly the number of fruits per plant.

Increasing plant spacing resulted in higher number of seeds per plant, independent of pollen amount (Table 1). It was a reflex of both the increased number of fruits per plant and the tendency to obtain more seeds per fruit when increasing plant spacing. Plant spacing did not influence the number of seeds produced per hectare, showing that an increasing number of seeds per plant in a higher plant spacing compensated lower population. The results pointed the plant spacing of 0.8 x $0.9 \mathrm{~m}$ as the most adequate. Since fewer plants would be necessary to obtain the desired yield in a certain area, crop management would be easier (manual pollination, spraying and harvesting) and some plant diseases would not be favored.

Considering the influence of pollination, using $50 \%$ of an anther on female flower stigma, results in significant lower values of seed weight per plant and per hectare when compared to total anther (Table 1). These results are according to Quesada et al. (1996) and Schlichting et al. (1987), who described that using low pollen amounts, squash fruits showed lower seed quantities in comparison to the use of high pollen amounts. In this work, although the pollen amount did not influence the number of fruits per plant, it affected the seed yield, showing its importance on hybrid seed production (Table 1). For seed yield, artificial pollination can be as effective as natural pollination, as long as a higher pollen amount is used.

The number of seeds per plant and per area shows the importance in the hybrid seed production, where high seed costs must be compensated with high yield. A lower pollen amount decreased the yield potential when compared to the natural pollination and the use of a whole anther (Table 1). That fact indicates that in the manual hybridization, at least one whole anther must be used.

Free (natural) insect pollination treatments are not controllable, varying according to climatic conditions, surrounding vegetation and the presence of pollinating insects. However, generally the tendency of the natural pollination values is identical to the pollination using an entire anther. So, for the conditions of this experiment, the pollen amount placed by insects in the C. Pepo female flower stigma is probably higher than the amount of half anther (Table 1).

These results allow to conclude that pollination and/or pollen amount showed a high economic importance on commercial seed production, affecting significantly the yield per area, contrary to plant spacing.

Increasing plant spacing resulted in higher seed yield per plant (Table 1). Demattê et al. (1978) mentioned that Caserta squash fruits obtained in high density planting showed lower seed yield per plant when compared to lower planting density. Loy (1988) mentioned that a low seed yield per plant is due to small weight or quantity of fruits in high density planting. High plant population causes competition for place, light and nutrients resulting in a lower seed production per fruit and per plant, and small fruits with lower weight. Ho (1992) mentioned that the production of growing substances in the presence of seeds stimulates the fruit growth, confirming the idea that higher seed amount per fruit results in bigger fruits.

The higher the plant spacing, the higher the SI (Table 1). SI value 
Table 2. One hundred seeds weight (100SW) and seed germination at on first count (C1 SG), according to plant spacing (PS) and pollen amount (PA) in Caserta squash. São Manuel, UNESP, 1998.

\begin{tabular}{|c|c|c|c|c|c|c|}
\hline & & $100 S W(g)$ & & & C1 SG (\% & \\
\hline PAPS (m) & $0,8 \times 0,3$ & $0,8 \times 0,6$ & $0,8 \times 0,9$ & $0,8 \times 0,3$ & $0,8 \times 0,6$ & $0,8 \times 0,9$ \\
\hline Natural & 9,81 b A & 10,21 b B & 12,41 a $A$ & 55,80 b A & 71,40 a $A$ & $52,40 \mathrm{~b} B$ \\
\hline $50 \%$ anther & 9,88 b A & 10,75 b AB & 12,88 a $A$ & 56,00 a $A$ & 58,60 a $B$ & 52,20 a $B$ \\
\hline $100 \%$ anther & $10,04 \mathrm{~b} \mathrm{~A}$ & 12,33 a $A$ & 11,88 a $A$ & 58,20 b A & 69,40 a $A$ & 67,80 a $A$ \\
\hline
\end{tabular}

Average followed by the same small letter on lines and capital on columns did not differ by Tukey test (5\%).

Table 3. Seed germination (SG) and emergence velocity index (EVI), according to plant spacing (PS) and pollen amount (PA) in Caserta squash. São Manuel, UNESP, 1998.

\begin{tabular}{|c|c|c|c|c|c|c|}
\hline & \multicolumn{3}{|c|}{ SG (\%) } & \multicolumn{3}{|c|}{ EVI } \\
\hline PA/PS (m) & $0,8 \times 0,3$ & $0,8 \times 0,6$ & $0,8 \times 0,9$ & $0,8 \times 0,3$ & $0,8 \times 0,6$ & $0,8 \times 0,9$ \\
\hline Natural & 97,40 a $A$ & 98,02 a $A$ & 96,60 a $A$ & 47,87 a $A$ & 49,78 a $A$ & 49,60 a $A B$ \\
\hline $50 \%$ anther & 91,65 b B & 91,40 b B & 97,80 a $A$ & 46,93 a $A$ & 49,67 a $A$ & 46,96 a $B$ \\
\hline $100 \%$ anther & 96,20 a $A$ & 97,40 a $A$ & 96,20 a $A$ & 47,47 b A & $49,71 \mathrm{ab} A$ & 52,32 a $A$ \\
\hline $\mathrm{CV}(\%)$ & \multicolumn{3}{|c|}{3,52} & \multicolumn{3}{|c|}{4,01} \\
\hline
\end{tabular}

Average followed by the same small letter on lines and capital on columns did not differ by Tukey test (5\%).

obtained in $0.8 \times 0.9 \mathrm{~m}$ plant spacing was $25.4 \%$, not very different from $28.2 \%$, considered by Loy (1988) as a high one, although genetic differences must be considered. SI increases as seed weight does for the same fruit mass. Results showed that an increase of the plant seed production is possible without increasing fruit weight, as long as the pollen amount is increased or, probably, the insect pollination amount, since an artificial pollination was as efficient as natural pollination for SI values.

A high weight of one hundred seeds $(100 \mathrm{SW})$ was reached with a low population density $(0.8 \times 0.9 \mathrm{~m})$. However, the use of whole anthers and spacings of $0.6 \mathrm{~m}$ and $0.9 \mathrm{~m}$ resulted in the same seed weight (Table 2). The occurrence of higher $100 \mathrm{SW}$ value with increasing plant spacing, does not confirm Dajoz's statement, mentioned by Demattê et al. (1978), that the relation of increased plant competition would result in a lower number of seeds produced per plant, but the seed weight would be consistent. On the other hand, Nakagawa (1986) mentioned that increasing plant population reduces the number of fruits and seeds per plant, as well as increasing the size. In this experiment, the difference between the employment of half an anther or a whole one did not increase $100 \mathrm{SW}$ significantly, independently of plant spacing used. Demattê et al. (1978) concluded that no significant difference was obtained in the average weight of one hundred seeds, considering perfect fruits, using one to three plants (Caserta squash IAC 1767) per hole in the same spacing. Since the number of seeds per plant was reduced as planting density was increased (Table 1), a higher 100SW of a $0.9 \mathrm{~m}$ plant spacing resulted in greater seed yield (weight) per plant. Certainly, the fact that seeds would be formed first (in number) and after that the filling process would be initiated (weight) interferes both in seed size and in yield per area. We could emphasize that $100 \mathrm{SW}$ can be considered a parameter both for yield and quality analysis. First because it enables the determination of seed weight, showing its size significantly, and second because the seed size may influence vigor and germination tests due to greater energy storage (Vieira \& Carvalho, 1994).

For Caserta, the best plant spacing was $0.8 \times 0.9 \mathrm{~m}$ and the pollen increased amount provided a greater seed yield. The pollination or pollen amount showed a great economic importance for the seed production, because it interfered in yield per area significantly.

\section{Seed quality}

Increasing pollen amount or using natural pollination did not affect the first count of germination test (Table 2) in high planting density conditions $(0.8 \mathrm{x}$ $0.3 \mathrm{~m}$ ). In a manual pollination the vigor might be missed with reduced pollen amount, mainly in higher plant spacing. Quesada et al. (1996) observed that squash hybrid seeds obtained through application of high pollen amounts, germinated faster, as occurred in this experiment. For this characteristic, manual pollination with a whole anther did not differ from the natural one in a high plant competition, but for the highest plant density the performance was better.

Concerning the emergence velocity index (EVI), using a whole anther, provided higher values if compared to the use of a half anther in a $0.8 \times 0.9 \mathrm{~m}$ plant spacing (Table 3). Thus, as occurred on the first SG counting, it was observed that when a factor was not a restriction $(0.8 \times 0.9 \mathrm{~m}$ plant spacing or whole anther), the other factor was important. Using a whole anther resulted in higher EVI if compared to a half anther in a $0.8 \times 0.9 \mathrm{~m}$ plant spacing and, 
in this plant spacing, there is more EVI (compared to a lower plant spacing) when a whole anther pollen amount is used. When one factor was limited, (high planting density or less pollen amount) the other factor had no importance in this seed quality parameter.

The importance of searching a higher EVI is found in the fact that with a higher germination rate, seeds and seedlings are less susceptible to damping-off diseases or produce transplants rapidly, reducing the cycle.

The use of a whole anther and natural pollination provided better germination percentage (final counting) when compared to the use of a half anther in the $0.8 \times 0.3 \mathrm{~m}$ and $0.8 \times 0.6 \mathrm{~m}$ plant spacing (Table 3). In $0.8 \times 0.9 \mathrm{~m}$ plant spacing no influence of pollen amount was found, what allows us to conclude that the lower competition between plants provided favorable conditions for seed quality gain, compensating losses caused by low pollen amounts.

There was no germination difference, using the same plant spacing and seed obtained through higher pollen amounts and natural pollination. Edelstein et al. (1985), mentioned that different squash cv. Spaghetti Vegetable population densities did not affect germination percentage. Finally, when using higher pollen amounts or natural pollination, a non-reduced germination in high density plant spacing is allowed. This is an important fact, as long as the germination percentage of squash seeds is legally the most important, since its value is showed on the label of commercial packages.

Based on the results, the EVI and the SG first counting showed similar influence to the seed vigor. In general, different from the first counting, one of the factors should be restricted in the SG final percentage so that the other factor could be expressed showing differences. In this case, plant spacing suffered influence just when the pollen amount was a restriction and when the pollen amount was important only to show the emphasized planting density.

Finally, the best plant spacing for the SG final percentage was $0.8 \times 0.9 \mathrm{~m}$, only when the pollen amount was half an anther and when the pollen increase provided a greater seed germination in all plant spacing.

\section{ACKNOWLEDGMENTS}

This work was supported by Fundação de Amparo à Pesquisa do Estado de São Paulo.

\section{CITED LITERATURE}

ANDRIOLO, J.L. Fluxo de carbono da planta. In Fisiologia das culturas protegidas. Santa Maria: Editora UFSM, 1999. p. 13-46.

ARAÚJO, E.F., MANTOVANI, E.C., SILVA, R.F Influência da idade e armazenamento dos frutos na qualidade de sementes de abóbora. Revista Brasileira de Sementes, Brasília, v. 4, n. 1, p. 77 87, 1982.

ÁVILA, C.J., MARTINHO, M.R., CAMPOS, J.P. Polinização e polinizadores na produção de frutos e sementes híbridas de abóbora (Cucurbita pepo var. melopepo). Anais da Sociedade Entomológica do Brasil, Viçosa, v. 18, n. 1, p. 13-19, 1989.
BRASIL. Ministério da Agricultura e Reforma Agrária. Regras para análise de sementes. Brasília: SNAD/CLAV, 1992. 365 p.

COUTO, R.H.N., PEREIRA, J.M.S., COUTO, L.A. Estudo da polinização entomófila em Cucurbita pepo (abóbora italiana). Científica, São Paulo, v. 18, n. 1, p. 21-27, 1990.

DEMATTÊ, M.E.S.P., CAMARGO, L.S., ALVES, S., NAGAI, V. Produção de sementes de Cucurbita pepo L. var. melopepo Alef. cv. Caserta IAC-1967 em três densidades de população. Científica, São Paulo, v. 6, n. 2, p. 165-173, 1978. EDELSTEIN, M., NERSON, H., PARIS, H.S., KARCHI, Z., BURGER, Y., ZOHAR, R. Hybrid seed production in spaghetti squash (Cucurbita pepo L.) using ethephon and honeybees. Hassadeh, v. 65, n. 12, p. 2416-2419, 1985.

HO, L.C. Fruit growth and sink strength. In: MARCHALL, C., GRACE, J. Fruit and seed production: aspects of development, environmental physiology and ecology. Cambridge: University Press, 1992. p. 101-124.

LOY, J. B. Improving seed yield in hull-less seeded strains of Cucurbita pepo. Cucurbit Genetics Cooperative, n. 11, p. 72-73, 1988.

NAKAGAWA, J. Produção de sementes. Brasília: ABEAS, 1986. 61 p. (Sementes, 2)

QUESADA, M., WINSOR, J.A., STEPHENSON,

A.G. Effects of pollen competition on the reproductive performance in cucurbit hybrids (Cucurbitaceae): F1 and backcross generations. Canadian Journal of Botany, v. 74, n. 7, p. 11131118, 1996.

SCHLICHTING, C.D., DAVIS, L.E., STEPHENSON, A.G., WINSOR, J.A. Pollen competition and offspring variance. Evolutionary Trends in Plants, v. 1, n. 1, p. 35-39, 1987.

SILVA, J.B., NAKAGAWA, J. Estudo de fórmulas para cálculo da velocidade de germinação. Informativo ABRATES, v. 5, n. 1, p. 62-73, 1995. VIEIRA, R.D., CARVALHO, N.M. Teste de vigor em sementes. Jaboticabal: FCAV/FUNEP, 1994. $164 \mathrm{p}$.

VIGGIANO, J. Produção de Sementes em Cucurbitáceas. In: CASTELLANE, P.D., NICOLOSI, W.M., HASEGAWA, M. Produção de Sementes de Hortaliças. Jaboticabal: FCAV/ FUNEP, 1990. p. 95-112. 